\title{
A Study on Reasons and Solutions to Tour Guides' Ripping Off Tourist
}

\section{Changrong Ling}

Department of Tourism, Business School of Guangxi University, Guangxi, China.

Email: lcr8888@sina.com

Received May $14^{\text {th }}, 2013$; revised June $14^{\text {th }}, 2013$; accepted June $21^{\text {st }}, 2013$

Copyright (C) 2014 Changrong Ling. This is an open access article distributed under the Creative Commons Attribution License, which permits unrestricted use, distribution, and reproduction in any medium, provided the original work is properly cited. In accordance of the Creative Commons Attribution License all Copyrights (c) 2014 are reserved for SCIRP and the owner of the intellectual property Changrong Ling. All Copyright (C 2014 are guarded by law and by SCIRP as a guardian.

\section{ABSTRACT}

Most of the tourism products were sold by middlemen travel agencies. There is a very complex relationship between travel agencies and stakeholders. The phenomena including zero fee, debt fee and guides cheating are mess as cluster, which greatly damage the interests of consumers and destroy the image of the industry and market reputation. This thesis aims to analyze the root causes of travel agencies' interest demands and the game of chaos that is the low threshold set by tourism agencies, the error location in tour guide career, un-standard tourist products, and so on. And then it explores practical solutions and technical methods: 1) taking more specializers and professionals in tour guides; 2) making the unemployment relationship between tourism agencies and tour guides; and 3 ) setting up the standardization in tourist products, and so on.

\section{KEYWORDS}

\section{Travel Agency; Guides; Interest Demands; Game}

\section{The "Unspoken Tourism Rules" Caused by Market Phenomena}

We can always know the negative messages from media such as zero fee, debt fee, ripping off, jilting groups, and so on. The ordinary tourists become arbitrary ravaged and slaughtered lambs! In 2006, a tour guide named Jingmin $\mathrm{Wu}$ attracted lots of attentions for publishing a book, Call Me How Not To Kill You, unveiling the "Unspoken Rules" [1], which were reported one after another by CCTV's three flagship programs, One On One, Legal Report, and Tell It Like It Is [2]. But the phenomena are not fundamentally changed even to this day.

On Apr. $8^{\text {th }}$, 2011, after an article, named Tour Guide Left behind Tourists Shopping Rake Allocation Table: Silk Quilt's Commission is 200 yuan, was crazy preached on the internet, the whole society focused on tourism industry [3]. The travel agencies' disorder is evident. Actually all of the tourism experts know the hidden facts, but travel agencies still run business basically by the "Unspoken Rules". It's just generally believed that they are confirmed habits which are hard to get rid of.
Why do travel agencies' operation and service fall into these "shackles"? Why are the interest game conflictions among travel agencies, tour guides, tourists, tourist shops, tourism travel companies and scenic spots so strong? And we can even marvel at how could the tourism industry which should have been a happy industry in an embarrassing situation now? Why does the tour guide profession which should be honest fall into such a deep abyss? This cannot but make us rethink profoundly!

\section{The Analysis of Travel Agencies Operating Models}

Let's have a look at travel agencies operating models. Travel agencies' product is traveling routes. These routes do not have patents at all, and every travel agency can use them. This is one of the factors that the tourism industry is not standard. Most travel agencies set specialized routes according to market demands, while there are some travel agencies don't have their own specialized routes, and mainly depend on tourists. Specialized routes are scale operation, the costs are relatively fixed; the 
costs of unspecialized routes fluctuate wildly.

The travel agencies which organize group trips by the ways, such as advertisements, stores or regiment individual tourists from other travel agencies, are tour organizing agencies (their tour guides are national guides). After travel agencies and tourists have mutually agreed with the tourist destinations, the travel agencies should contact the travel destinations to receive the tourists, and the travel destinations here are tour operators (their tour guides are local guides). No matter tour organizing agency or tour operator, the one which can only operate domestic routes is national agency, and the one which can operate inbound and outbound routes is international agency (its tour guides are leaders).

Then let's have a look at tour guides' career [4]. The so-called tour guides are the one who have got the guide qualifications certificate, accepted brokerage firm's appointment, and provide tour guide service to tourists who are organized by the travel agencies. We can also call tour guides as service staffs. To put it simply, tour guides' responsibilities are leading and providing service to tourists to travel the whole tour routes with explanations. In other words, tour guides are the one who thread a needle among tour organizing agencies, tour operators, transportations, restaurants, hotels, scenic spots and shoppes, their interests have stakes in these links. It's just as a shuttle in a textile machine; the shuttle decides the spinning's quality and effectiveness.

Tour guides' effects are of vital importance, and they concern to the quality and effects of the whole tour. There are two management models for tour guides, one is affiliated to Tour Guide Service Center, the other is attaching to travel agencies. Generally speaking, tour guides don't have any basic salaries. Even though they have, the basic salaries are only between six hundred and eight hundred Yuan which is very low. Some tour guides have medical insurance, endowment insurance, unemployment insurance, while others don't have, and so on. In other worlds, there is no fundamental guarantee for tour guides. So it becomes inevitable that there are interest demands and game between tour guides and stakeholders. Here comes the "Unspoken Rules".

\section{The Reasons of Interest Demands and Game between Tour Guides and Stakeholders}

Interest demands and game between tour guides and stakeholders are mainly caused by tour guides' unreasonable salary structure, malignancy group, un-standard routes product, covenant lite to tour guides, and so on. The game routes model chart is showed as below.

1) The major defect in tour guides' salary structure and it's distributing way is the fundamental cause of interest demands and game. Tour guides generally don't have basic salary; the travel agency will give some tour subsidies which also named tour guide subsidies to them when they are taking missions, the subsidies vary from $50 \mathrm{Yu}$ an to 200 Yuan. Other income is from the purchase rebates and adding plots rebates (gently speaking is commission), namely tour guide subsidies plus rebates, without any other income. The tour guide subsidies are paid before taking missions, and the rebates are paid on the spot.

Is there any other career's salary structure and distributing way in the world similar to this career? The system missing of the industry put tour guides, the beautiful angels, into weak space without any security (Figure 1).

2) Malignancy group by zero and debt fee [5]. Trace back from the fundamental reasons to the source, namely travel agencies don't care about tour guides' interest and their value at all when they are taking group, certainly not care about tourists' consumption benefits and their culture demands. Travel agencies over compete on operating costs, competing to depress profit margins, so that there is no profit or even debt profit, and they have to sell the group to tour guides. Tour guides buy the group from travel agencies, and travel agencies get meager profit from tour guides, tour guides take the mission in debt. So, tour guides have to raise the butcher's knife to rip-off tourists!

3) Un-standard tourist products. Consumption comes after grouping. The tourist products provided by travel agencies have strong arbitrariness, large differences in travel time, lacking of rigid constraints. Immature tourists make price of tourist products full of elasticity, which varies according to different tourists and different time, and there is no standard for it. The price of routes products are made by travel agencies.

4) The trip power in tourist group activities is held by drivers. The leader who lead traveling are tour guides who are the core of the tourist groups, and this is uncontroversial. But no one knows when it began that tour guides don't have the voice which is held strongly by drivers during traveling. Most travel buses are belong to individuals, and they operate by adding or affiliating to tourist travel companies; even if the travel buses are belong to operating companies, they are contracted by drivers. There is no guarantee to drivers' qualities. Tour guides should try to please drivers on many things, such as which way to go, where to stop, how long to have a rest, turn on air-conditioning or not, which CD to play on the bus (even there are some vulgar CDs), and so on.

Tour guides themselves also become slaughtered sheep. Here comes the other "Unspoken Rule" between tour guides and drivers.

5) The low access threshold to tour guides. Because of low access threshold to tour guides which only requires 


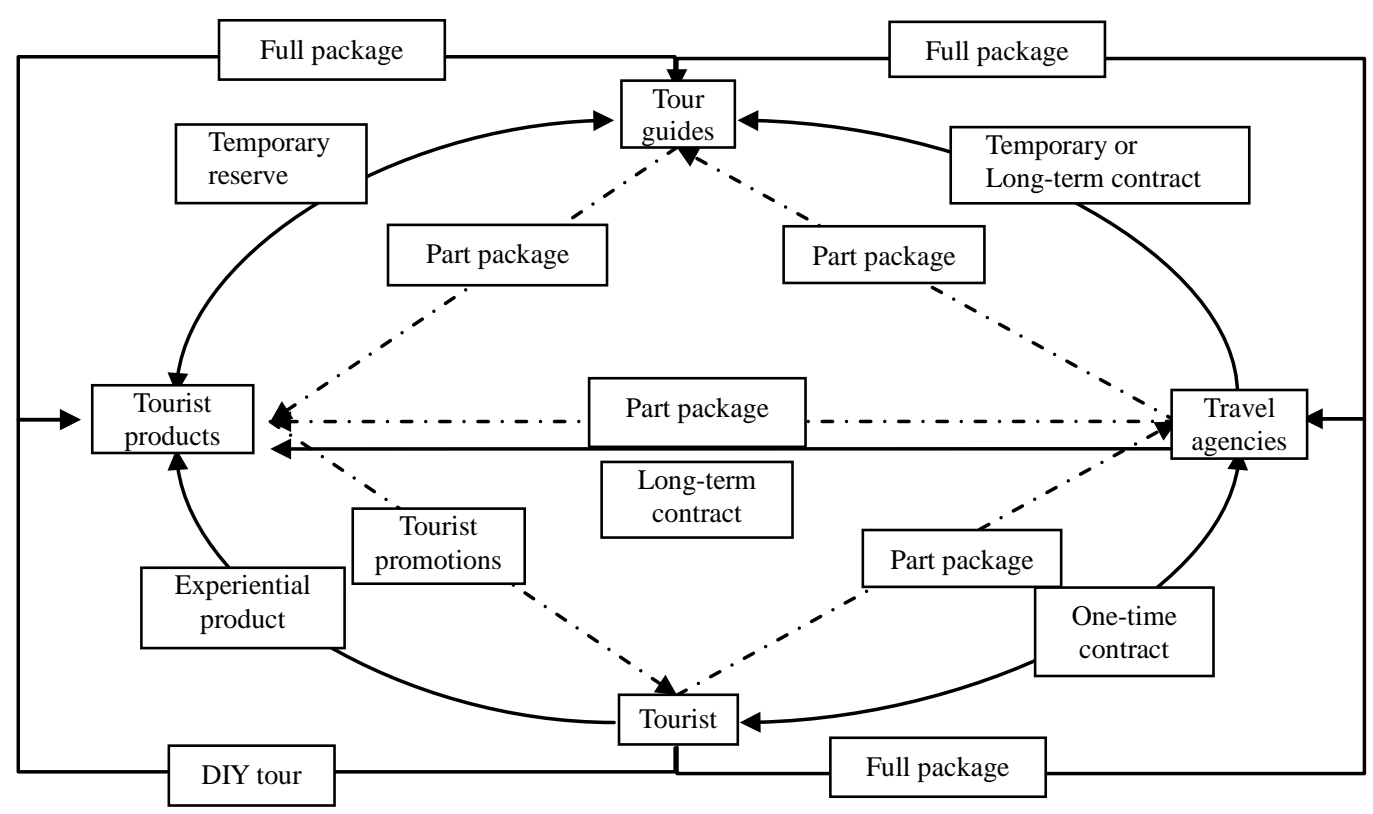

Figure 1. Game routes model.

secondary or high-school education, the socialization of tourist higher education, professional lagged education and the so-called "Unspoken Rules" in tourism industry, college graduates majored in tourism are daunting, and seldom engage in tourism industry after graduated, fewer to be tour guides. So that tour guides have poor education, low ages, shallow experience, narrow knowledge, so tour guides can’t but eat youth rice.

\section{The Paths for Interest Demands and Game Resolution}

It's not a bad thing to exposure problems. It's critical to face them bravely. For the source of the problems, I ventured to make the following suggestions:

1) Improving tour guides' professionalism. In the professional classification in our country, tour guides belong to service staffs, not specialty technical staffs. So it constraints the improvement on tour guides' professionalism. In fact, there's very high requirement for tour guides' professional techniques, at least higher than tourists' average levels. From this view, the relationship between tour guides and tourists are similar to which between professors and students. Professors imparting knowledge to students, teach them learning methods; while tour guides spread knowledge to tourists, teach them to realize objective things.

2) Setting travel agencies according to tour guides' quality and size. Tour guides are the core of travel agencies, but it's to our surprised that actually travel agencies could have no any their own tour guides! Or tour guides become vassals of travel agencies! It's just like there are no any doctors in an hospital, and no any professors in a university. This is the source of various stubborns in travel agencies, and also the main reason for complaints. Therefore, the setting of travel agencies should regard tour guides as the core indicators, establish tour guides' subject position, redistrict travel agencies' grade by professional tour guides' fixed title, grade and quantity.

3) Research on making tour guides' salary system, and the salary should be paid uniform by travel agencies namely paid by employers monthly. Using practices of most industries as reference, the salary structure of tour guides should be made of basic salary, performance fee, bonuses and other welfares to ensure tour guides' basic lawful incomes.

Tour guides can reduce pressure, have income guarantee, their working enthusiasm are mobilized, service quality will be improved and so is tourists satisfaction degree. Otherwise, years of practice have proved that if only it exists that "cash on delivery", the nature of benefit will make tour guides "greed and cynical". So it allows no delay to do the research on working out salary structure of tour guides, and uniform supervise and paid by travel agencies namely employers monthly.

4) It's prohibited to sell group to tour guides from travel agencies, and we must firmly stop the vicious competition of zero fee or debt fee. It refers to tourism products and price here. Tourism products should be uniform priced by industry association and industry standard, and approved by commodity price departments, making them standardize. It's very important! Travel agencies mustn't sell to the public in the price lower than the approved price.

You know, products of an industry are not endless and 
borderless, otherwise there is no credit nor standard to give. Products provided by travel agencies should be unified and standard, their price elasticities should have a limit. It's not restricting innovation of products, nor restricting flexible operation of companies, nor damaging consumers' interests, but on the contrary, it vindicate their interests. You know, "you get what you pay for" is always the market rule. Zero fee and debt fee damages tourists' interests, there's no doubt that tour guides will pass to consumers.

5) Tourism products should be standardized, especially on price hearing. Because cost can be estimated, the premise is tourism resources and their products are of public products and public benefits, and at the same time, market is based on legal foundation, if tourism products can be any priced, it will damage industry interest and also consumers' benefits, so that it will undermine the market order.

In fact, the prices of travel agencies are not marketable, they are sold on the premise that there's no quality nor quantity guaranteed. It is lacking of standards at reasonable prices nor their quality supervision. It is generally known that tourism products include material and spiritual products, but travel agencies sell them lower than the cost of material products, without any considering at the cost of spiritual products at all. So chaotic price lead to poor quality in tour guides' service and also lacking of honesty, cause lots of tourist complaints, even increase difficulty on tour guides' taking groups.

6) Standardize of tourism routes. What products travel agencies sold are mostly tourism routes, which are constituted by scenic spots, scenic areas, shops, hotels, entertainment places and so on. These products can completely standardize, otherwise there's no rules at all. In other words, they all can be designated procured in advance.

Whether scenic spots, scenic areas, shops, hotels, entertainment places, or translation vehicles, all of the tourism products, before selling to customers, should accepted by the competent department of the government and regulators, their prices should be approved by commodity price department, and designated procured by enterprise institutes or federations. That is, tourism products have to have sales qualification, and include in uniform sale network.

7) Purchase vehicles (include drivers) by tour guides, give the command of vehicles to tour guides, hold drivers' urge and power. Most local tour buses are private, and most are individuals. This in itself exist serious hidden dangers. There is a must to set up tour transportation companies, uniformly managed and operated, and individual business operations are forbidden.

We can imitate taxi management model to manage tour transportations. The relationship between tour guides and drivers is an employment relationship, on the premise of abiding by traffic rules, drivers have to act in unquestioning obedience to tour guides' command. Tour transportation should be also standardized.

So, interest demands and game of travel agencies products will be carried out in standard and regulation. "Unspoken Rules" chaos in tourism can be curbed.

\section{Complimentary Closes}

In 2009, the State Council of the People's Republic of China announced the introduction of "Views on the Acceleration of the Development of Tourism Industry" in the (2009) No. 41, put forward to develop tourism industry into a strategic pillar industry of the national economy and a modern service industry which people will be more satisfied with. Relative departments should find breakout paths for tour guides' career orientation and title promotion, and travel agencies should start from the self-discipline, set up tour guides' subject status, make the system first, normalized operation, standardized supply, and personalized service.

Then tourism industry can really become a happy industry, tour guides can really become a respectable career, and products of travel agencies can become bigger and stronger. Until then, tourists' basic interests can be protected, tourism industry can become a creating happiness industry and the flag of the national economy strategic pillar industry can fly high!

\section{REFERENCES}

[1] J. M. Wu, “Call Me How Not to Kill You,” 1st Edition, Huashan Art and Literature Press, Guangzhou, 2006.

[2] http://vip.book.sina.com.cn/pub/book.php?Book=447180

[3] http://news.sina.com.cn/s/2011-04-08/114222257681.sht $\underline{\mathrm{ml}}$

[4] The People's Republic of China Occupation Classification, 1999.

[5] J. R. Zhang and Z. Z. Zhan, "Research on Tour Guides Employment, Salary and Security System in China,” 1st Edition, China Travel and Tourism Press, Beijing, 2008. 